\title{
Scientific note: first global report of a bee nest built only with plastic
}

\author{
Mariana L. Allasino ${ }^{1}$, Hugo J. Marrero ${ }^{2}$, Jimena Dorado ${ }^{3}$, Juan Pablo Torretta ${ }^{4}$ \\ ${ }^{1}$ Instituto de Investigación y Desarrollo Tecnológico para la Agricultura Familiar Región Cuyo, INTA, San Juan entre Sarmiento y \\ José Pedro Cortinez Oeste, 5439 San Martín, San Juan, Argentina \\ ${ }^{2}$ Centro de Recursos Naturales Renovables de las Zonas Semiáridas, CONICET, Camino de la Carrindanga Km. 7, 8000, Bahía \\ Blanca, Argentina \\ ${ }^{3}$ Instituto Argentino de Investigaciones de las Zonas Áridas, CONICET, CC 507, 5500, Mendoza, Argentina \\ ${ }^{4}$ Cátedra de Botánica General, Facultad de Agronomía, Universidad de Buenos Aires and CONICET, Av. San Martín 4453, \\ C1417DSE, Buenos Aires, Argentina
}

Received 8 November 2018 - Accepted 28 January 2019

\begin{abstract}
Agricultural plastic waste can alter wildlife diversity and behavior. Species survival will depend on their ability to adapt to new environmental conditions. In a seed-producing farm, a Megachile sp. nest made fully with plastic was found in a trap nest. This record represents the first one worldwide on revealing the use of plastic in the total construction of a bee nest.
\end{abstract}

solitary bees / plastic / adaptive flexibility

\section{INTRODUCTION}

Conventional farms depend largely on the use of external inputs (Scarascia-Mugnozza et al. 2012). Many of these inputs generate plastic waste. The discarding of agricultural plastic waste is frequent, and it subsequently accumulates in agroecosystems (Hemphill 1993) (Figure 1a). Plastic is used in many ways, including greenhouses, mulching, small tunnels, temporary coverings of fruit trees, liquid agrochemicals' containers, fertilizer bags, and hoses for drip irrigation, among others (Briassoulis et al. 2013).

The accumulation of plastic waste has as a consequence several environmental impacts (Barnes et al. 2009), such as changes in wildlife behavior and biodiversity (Suárez-Rodriguez et al. 2017). The adaptive capacity to selective pressures exerted in the landscapes enables some species to persist over others (Shochat et al. 2006). An indication of this adaptive capacity of species over human disturbances could be the exploitation of artificial materials present in the habitat

Corresponding author: M. Allasino,

allasino.mariana@inta.gob.ar

Manuscript editor: Yves Le Conte
(MacIvor and Moore 2013). The use of human-made materials has been recorded in animals, although there are very few documented cases for insects (Medler 1966, MacIvor and Moore 2013).

Pollinators are a key component of the insect diversity associated to agroecosystems, as they provide a key service for its proper functioning (Klein et al. 2007; Garibaldi et al. 2013). However, numerous populations of different bee species are currently decreasing in an alarming way worldwide (Potts et al. 2010; IPBES 2016). One of the main causes of their decline is human disturbance (Rundlöf et al. 2015).

Bees (Hymenoptera: Apiformes) are the most efficient pollinators worldwide (Free 1993; Michener 2000). Species of the family Megachilidae are solitary bees and many of them nest in preexisting cavities using materials collected from landscape such as mud, stones, leaves, petals, and resins to build brood cells (Sheffield 2017). Each cell holds a larva which will develop into an adult bee.

During 2017-2018 spring-summer, a study was conducted on pollinators of chicory (Cychorium intybus) for seed production in San Juan, Argentina $\left(31^{\circ} 40^{\prime} 58.7^{\prime \prime} \mathrm{S}, 68^{\circ} 31^{\prime} 25.3^{\prime \prime} \mathrm{W}\right)$. In addition to other sampling methods, 63 trap nests were placed on the crop's edges. The trap nests were checked monthly to record nest building. Only three nests were found, two belonging to Megachile jenseni Friese made out of 


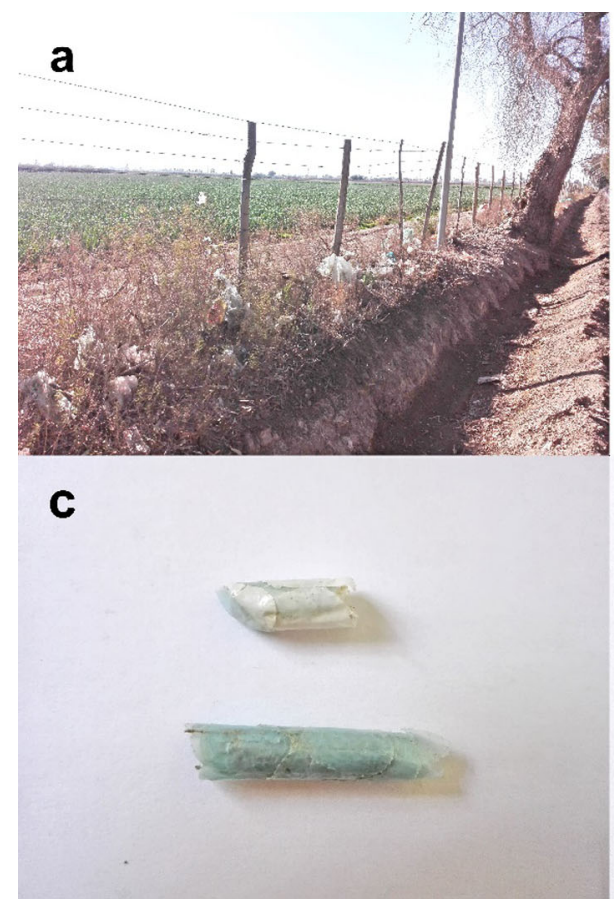

\section{b}
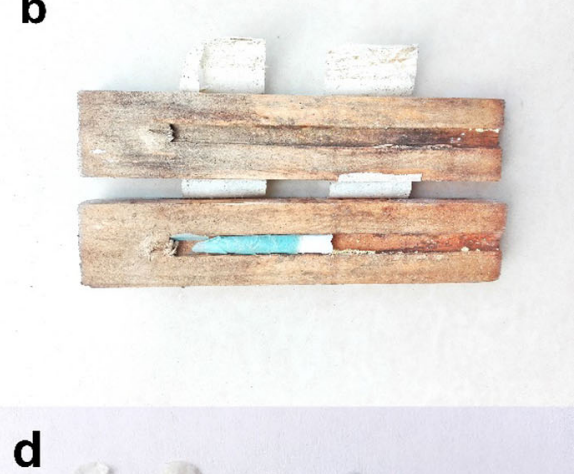

d

Figure 1 a Plastic waste on crop's edges, b plastic nest of Megachile sp. (Megachilidae) built in a nest trap, c plastic brood cells built in a nest trap, $\mathbf{d}$ circular and oblong plastic pieces of the cells.

petal cells and mud partitions (confirmed by the emergence of five adults) and one with cells built fully with two types of plastic (Figure 1b).

The plastic nest found was formed by three cells of $1.27 \pm 0.12 \mathrm{~cm}$ (Figure 1c). The cells were composed by circular and oblong plastic pieces $(9.76 \pm 1.81 \times 6.57 \pm$ $0.96 \mathrm{~mm}, n=54$ ) arranged in an imbricated manner (Figure 1d). The first two cells were only formed by light blue plastic of shopping bag consistency. The third cell was made entirely of white plastic, thicker than the previous one. Among the three cells, one contained a dead larva; from the other, the adult seemed to have emerged from the nest; and the third cell was not finished. For this reason, we do not know the identity of the species that built the nest. However, it could be Megachile rotundata (Fabricius), an exotic species caught in flowers of our study site, and for which there is a record of plastic use as brood cell material (MacIvor and Moore 2013). This exotic species of Megachile has been introduced for commercial purposes and is widely established in Argentina (Álvarez et al. 2012). In addition, for commercial populations of this species (cited as M. pacifica Panzer), Richards (1978) reports the use of artificial substrates including plastics such as polymers, styrofoam, and polystyrenes. Furthermore, taking into account that the selection of leaves by Megachile species has probably evolved as an adaptation to the local environment (Kambli et al. 2017) and that M. rotundata is an exotic species in Argentina, the idea that the nest has been built by a female of this species could certainly be a possibility.

So far, the only record of plastic use by bees in the nest construction was that described by MacIvor and Moore (2013). Nests of M. rotundata and M. campanulae (Robertson) were found, where three and two cells were respectively constructed with plastic. However, the nest reported here is novel in two ways: (1) plastic is the only material used for brood cell construction in the nest and (2) two types of plastic were used.

The use of plastic as a resource for nest construction suggests that certain species of bees would have adaptive flexibility in the face of changes in environmental conditions. The replacement of natural materials by plastic could appear in response to a limitation in the availability of vegetation in the fields, which could be directly linked to the use of herbicides (Nicholls and Altieri 2013). On the other hand, the use of plastic as the only resource for the construction of the nest could be associated with the preference of this material over natural ones. Some evidence shows that the use of synthetic materials in nesting could bring adaptive advantages (Suárez-Rodríguez et al. 2012). We cannot determine if plastic in the construction of the nest would 
bring adaptive advantages to bees. However, it could highlight bees' response capacity in the search for alternative materials for the construction of their nests in the face of human disturbance.

\section{ACKNOWLEDGMENTS}

We would like to thank Diego Vázquez for valuable comments on an earlier version of the manuscript and José Martín for allowing us to work in his field.

\section{AUTHOR CONTRIBUTIONS}

MLA and HJM conducted field sampling; MLA, HJM, $\mathrm{JD}$, and JPT analyzed the data and wrote the paper. All authors read and approved the final manuscript.

\section{FUNDING INFORMATION}

This study was supported by the INTA fellowship Disp. No. 942/15, Res. No. 108/17, PRET VAyNE-1251510, PROFEDER-785140, and PANAPI-1112044.

\section{COMPLIANCE WITH ETHICAL STANDARDS}

Conflict of interest The authors declare that they have no conflict of interest.

Note scientifique: premier rapport mondial sur un nid d'abeille construit uniquement en plastique

abeilles solitaires / plastique / flexibilité adaptative

Wissenschaftliche Notiz: Erster weltweiter Nachweis, dass ein Bienennest ganz aus Plastikresten gebaut sein kann

\section{solitäre Bienen / Plastik / adaptive Flexibilität}

Publisher's note Springer Nature remains neutral with regard to jurisdictional claims in published maps and institutional affiliations.

\section{REFERENCES}

Álvarez, L. J., Lucia, M., Durante, S., Pisonero, J., Abrahamovich, A. H. (2012). Occurrence of the exotic leafcutter bee Megachile (Eutricharaea) concinna (Hymenoptera:
Megachilidae) in southern South America. An accidental introduction? J Apicult Res. 51, 221-226.

Barnes, D. K., Galgani, F., Thompson, R. C., Barlaz, M. (2009) Accumulation and fragmentation of plastic debris in global environments. Philos T RoySoc B. 364, 1985-1998.

Briassoulis, D., Babou, E., Hiskakis, M., Scarascia, G., Picuno, P., Guarde, D., Dejean, C. (2013). Review, mapping and analysis of the agricultural plastic waste generation and consolidation in Europe. Waste Manage Res. 31(12), 1262-1278.

Free, J. B. (1993). Insect pollination of crops. Acad. press, London, U.K.

Garibaldi, L. A., Steffan-Dewenter, I., Winfree, R., Aizen, M. A., Bommarco, R., Cunningham, S. A., et al. (2013). Wild pollinators enhance fruit set of crops regardless of honey bee abundance. Science. 339(6127), 1608-1611.

Hemphill, D. D. (1993). Agricultural plastics as solid waste: what are the options for disposal? Hort Technology. 3(1), 70-73.

IPBES. (2016). Summary for policymakers of the assessment report of the Intergovernmental Science-Policy Platform on Biodiversity and Ecosystem Services on pollinators, pollination and food production [online] http://www.ipbes. net/sites/default/files/downloads/SPM_Pollinators_unedited\%20advance.pdf.. Accessed 13 Oct 2018.

Kambli, S. S., Aiswarya, M. S, Manoj, K., Varma, S., Ash, G., Rajesh, T. P., Sinu, P. A. (2017). Leaf foraging sources of leafcutter bees in a tropical environment: implications for conservation. Apidologie. 48, 473-482.

Klein, A. M., Vaissiere, B. E., Cane, J. H., Steffan-Dewenter, I., Cunningham, S. A., Kremen, C., Tscharntke, T. (2007). Importance of pollinators in changing landscapes for world crops. Proc R Soc London Ser B. 274(1608), 303-313.

MacIvor, J. S., Moore, A. E. (2013). Bees collect polyurethane and polyethylene plastics as novel nest materials. Ecosphere. $4(12), 1-6$

Medler, J. T. (1966). A resin bee using trap-nests in Wisconsin, and a note on other resin bees (Hymenoptera: Megachilidae). Entomol News. 77, 228-230.

Michener, C. D. (2000). The bees of the world, 1st edition. Johns Hopkins University Press, Baltimore.

Nicholls, C. I., Altieri, M. A. (2013). Plant biodiversity enhances bees and other insect pollinators in agroecosystems. A review. Agron Sustain Dev. 33(2), 257-274.

Potts, S. G., Biesmeijer, J. C., Kremen, C., Neumann, P., Schweiger, O., Kunin, W. E. (2010). Global pollinator declines: trends, impacts and drivers. Trends Ecol Evol. 25(6), 345-353.

Richards, K. (1978). Comparisons of nesting materials used for the alfalfa leafcutter bee, Megachile pacifica (Hymenoptera: Megachilidae). Can Entomol. 110, 841-846.

Rundlöf, M., Andersson, G. K., Bommarco, R., Fries, I., Hederström, V., Herbertsson, L., Smith, H. G. (2015). Seed coating with a neonicotinoid insecticide negatively affects wild bees. Nature. 521(7550), 77.

Scarascia-Mugnozza, G., Sica, C., Russo, G. (2012). Plastic materials in European agriculture: actual use and perspectives. $\mathrm{J}$ Agr Eng Res. 42(3), 15-28. 
Sheffield, C. S. (2017). Unusual nesting behavior in Megachile (Eutricharaea) rotundata (Hymenoptera: Megachilidae). Journal of Melittology, (69),1-6.

Shochat, E., Warren, P. S., Faeth, S. H., McIntyre, N. E., Hope, D. (2006). From patterns to emerging processes in mechanistic urban ecology. Trends Ecol Evol. 21(4), 186-191.
Suárez-Rodríguez, M., López-Rull, I., Macías García, C. (2012). Incorporation of cigarette butts into nests reduces nest ectoparasite load in urban birds: New ingredients for an old recipe? Biol Lett. 9(1), 20120931.

Suárez-Rodríguez, M., Montero-Montoya, R. D., Macías Garcia, C. (2017). Anthropogenic nest materials may increase breeding costs for urban birds. Front Ecol Evol. 5, 4. 